\title{
Agency Costs in Family Business: A Review
}

\author{
Shuran Li, Xiaode Zuo* \\ School of Management, Jinan University, Guangzhou, China \\ Email: 1sr2017now@163.com, ^tzuoxd@jnu.edu.cn
}

How to cite this paper: Li, S. R., \& Zuo, X D. (2020). Agency Costs in Family Business: A Review. Journal of Service Science and Management, 13, 377-387. https://doi.org/10.4236/jssm.2020.132025

Received: March 12, 2020

Accepted: April 25, 2020

Published: April 28, 2020

Copyright (c) 2020 by author(s) and Scientific Research Publishing Inc. This work is licensed under the Creative Commons Attribution International License (CC BY 4.0).

http://creativecommons.org/licenses/by/4.0/

\begin{abstract}
Family business occupies an important position in the national economy of all countries in the world. The theoretical field has always been controversial about the agency costs of family businesses. This article reviews the agency conflicts in family businesses and the resulting agency costs. Relevant literature found the particularity and complexity of agency costs for family businesses. Finally, we proposed an agenda for future research.
\end{abstract}

\section{Keywords}

Family Firms, Agency Cost, Altruism, Governance Mechanism

\section{Introduction}

Families and businesses have been writing business history together. Family businesses are the oldest and universally significant corporate organization in the world. In the world economy, families are one of the most important shareholders in business organizations. In all countries around the world, both developed and developing countries, family businesses are stubbornly growing and developing. Studies show that globally, the proportion of family-controlled listed companies is very large. With $10 \%$ control as the control standard, family holding companies in Europe are as high as $55.87 \%$, Asia is $45.05 \%$, and the United States is $36.6 \%$; with $20 \%$ control as the control standard, the proportion of family holding companies in Europe is $44.29 \%$, Asia is $37.86 \%$, and the United States is $19.82 \%$. There are many definitions of family business, and there is basically a consensus that when family members own most of the company's shares and participate in management, are members of the board of directors, and want to spread the company to future generations, the company is a family business (Salvato \& Corbetta, 2013). Managers of family businesses can be divided into two categories: family managers and professional managers. Family members not only pursue economic goals, but also aim to maintain social emotional 
wealth (Cennamo et al., 2012).

Family businesses have raised new and challenging agency cost issues. For a long time, the academic community generally believed that companies using the family management model had lower agency costs than non-family businesses. The management right is unified, the interests of the owner and the family manager tend to be the same, which reduces the possibility of opportunistic behavior of the family manager; and the degree of information asymmetry between family members is low, which solves the problem of the principal and the agent Information asymmetry between people. After entering the 21st century, a group of scholars represented by Schulze challenged this traditional view. From the perspective of altruistic theory, they proposed that the agency problem of family businesses has its own special characteristics. When altruism has a negative effect, the agency cost of a family firm is higher (Lubatkin et al., 2010). After this new viewpoint was published in some mainstream management journals (such as "Organization Science"), the international academic community has been increasingly controversial on this issue.

Due to the importance of the status and role of listed family companies in the global economy, the issue of agency conflicts is an important factor affecting the development and growth of family companies. Reducing agency costs is also one of the goals of family companies to maximize corporate value. Therefore, it is necessary to strengthen research on agency costs for family businesses. Since the 1970s, a large number of scholars have followed up the study of agency costs of family businesses. Scholars have explored the sources of agency costs of family businesses and the relationship between altruism and agency costs, and have carried out exploratory and empirical studies, but the academic community has not reached an agreement on the relationship between the family management model and the agency cost, and the literature review research in this field is very lacking. In order to fill and enrich the related research fields, this article aims to review the literature on agency costs in family businesses one by one, and lay the foundation for further research.

\section{Sources of Agency Costs for Family Businesses}

Scholars usually use the principal-agent theory as a tool to analyze the contract between the principal and the agent. The principal delegates the work to the agent. It is expected that the agent will complete the principal's requirements in the best interest of the principal (Eisenhardt, 1989). The agency cost theory is based on the relationship between the principal and the agent. The agency problem stems from the assumption that the agent will take opportunistic behavior, especially when there is a conflict of interest between the agent and the principal (Mitchell \& Meacheam, 2011). The opportunistic behavior of agents can be divided into three categories: moral hazard, adverse selection, and rip-off. Due to the separation of ownership and management rights, there is an agency conflict between the owner and the manager, and the manager's behavior may deviate from the principle of maximizing the owner's interests, leading to the emergence 
of agency costs (Jensen \& Meckling, 1979). The source of agency costs is the potential conflict between the agent and the principal. In order to control agency issues, the principal needs to invest in agency costs. Agency cost is the sum of monitoring cost (Monitoring Cost, Bonding Cost, and Residual Cost) (Jensen \& Meckling, 1979). Monitoring cost is used to establish an appropriate incentive mechanism for the agent. Constraint cost is used to pay the agent Human resources cost appropriately. Residual loss is the difference between the agent's decision and the client's own utility to maximize the decision (Xiang et al., 2014). In any case, only when the manager pursues his own interests and violates the owner's interests Agency costs are only incurred at the time (Chrisman \& Patel, 2012). In family businesses, agency problems in family businesses are embedded in parent-child relationships characterized by altruism and established in the family. Altruism, private ownership and family management are intertwined, and unique agency conflicts come from sources other than the classic principal-agent problem. This article sorts out the typical conflicts of family businesses:

Conflicts of interest between family members in different roles: when some family members have only ownership and other family members have both ownership and management rights, the principal (the family member who only owns the ownership) and the agent (the family member who also participates in the business), conflicts may arise. This situation may reduce altruism and effective collaboration and information exchange, thereby increasing agency costs; conflicts of interest between major family shareholders, and the financial and non-financial benefits of multiple family owners may be different, leading to potential family disputes and conflict. This conflict undermines the benefits of collective power exercise as a unified group of major shareholders, including the indisputable extraction of private benefits of family control, supervision of managers, and non-economic benefits derived from them. Controlling and nurturing companies through the family's own strategic preferences (Chrisman \& Patel, 2012). In addition, this family conflict creates a centrifugal force that undermines family cohesion. If left unaddressed, these impacts could undermine the ongoing impact of family groups as a powerful economic and social actor and ultimately herald the decline of a collective organization (Franks et al., 2012). The family usually separates the homeowner from its assets and creates a buffer by establishing an intermediate organizational entity, such as a home office or home trust, to avoid uncoordinated interference in the family's business activities, thereby limiting the damage caused by the conflicts of the major shareholder of the family Sex. However, this solution incurs another agency cost, the double agency cost (Carney et al., 2013). All in all, the heterogeneous interests among family owners have led to conflicts among the major shareholders of the family, and these conflicts have been largely ignored in the existing academic literature on family agency issues.

Conflicts of interest between family members and non-family members: Both family members and non-family members may have ownership and management rights and therefore have different roles, such as owner-manager, owner of 
board members, owner, non-ownership Manager and non-owner board member. If the owner self-manages the company and other shareholders who do not manage the business co-ownership of the company, or jointly with the non-owner manager, the agency costs come from the owner manager and the owner or owner manager who is not involved in managing the business Conflicts with non-owner managers (Chrisman, Chua, \& Litz, 2010). In such cases, family businesses need mechanisms that can promote solidarity between families and non-family members. In addition, if non-family members (usually professionals) are better managers than family founders and their heirs, the cost of the family management model may be quite high;

Conflicts of interest between major shareholders (family shareholders) and minority shareholders (non-family shareholders): Due to the existence of two forces that protect major shareholders and reduce their protection, major shareholders can use their positions to squeeze the interests of minor shareholders and seek Private interest, which incurs agency costs for minority shareholders.

Conflicts of interest between owners and creditors: The founding family business has an incentive mechanism that can reduce agency conflicts between shareholders and creditors, making its debt financing costs significantly lower than non-family businesses. Conflicts of interest between creditors and owners of family businesses can lead to inefficient investment behaviors, but inefficient investment behaviors vary depending on the nature of the company's assets.

\section{Altruism and Agency Costs of Family Business}

Altruism provides a powerful conceptual tool to explain why family businesses exist. Altruism plays a unique role in family businesses, which does not necessarily appear in other businesses. According to Becker, altruism is "self-enforced" and essentially selfish, because individuals pursue their maximal utility in the process of taking altruistic actions (Vanden \& Carchon, 2003). Some scholars believe that the enterprise adopting the owner management system does not exist or has a small agency cost (Jensen \& Meckling, 1979; Fama \& Jensen, 1983a; 1983b), and because family members in family businesses are considered altruistic, This perception tends to extend into the field of family business. However, Schulze et al. (2003a; 2003b) integrated social factors into the agency framework to study and came to the negative conclusion that altruism will increase agency costs. Therefore, the field of family business research is controversial about the relationship between altruism and agency costs. To better explain the relationship between family business altruism and agency costs. Stewardship theory, as a supplement to the agency theory framework, can better explain the behavior of enterprises and organizations. The altruistic hypothesis in the steward's theoretical framework is truly unrewarding and non-self-interested, which is different from the concept of altruism adopted in economic theory and often used in agency theory research (Corbetta \& Salvato, 2004). Agency theory tends to think that agents will try to take opportunistic behavior under any background condi- 
tions, while organizational justice theory disputes this assumption, thinking that corporate agents value fairness and justice, and only when they think they have been treated unfairly. Take opportunistic behavior. In addition, scholars have combined economics with organizational justice and unified the two under the general agency framework in an attempt to resolve the dispute over the relationship between altruism and agency problems (Lubatkin et al. 2007).

Some scholars believe that altruism can enable family members to love each other, safeguard family interests, and be conducive to the growth of family businesses (Becker, 1981). Due to the impact of altruism in family businesses, agency costs can be reduced through informal contracts, benefit bundling, and risk sharing (Daily \& Dollinger, 1992). Although altruism can reduce some agency costs, it can also lead to other problems, such as the "free-rider" phenomenon, the inability of family member managers, predatory managers, and trenching tendencies (Bruce, Waldman, 1990). Some authors believe that trenches lead to greater agency conflicts in family businesses than non-family businesses (Morck \& Yeung, 2010). Altruism can facilitate the transmission of tacit knowledge among family members, and good communication makes family business decisions better (Gersick et al., 1997). Altruism helps encourage family members to reduce agency costs and thereby improve the performance of family businesses (Vanden \& Carchon, 2003). Family members bring altruism in the family into the family business, which is conducive to fostering loyalty and commitment to the long-term goals of the business, reducing the agency costs of the company (Wang et al., 2005). When the strength of altruism is consistent among family members, family business owners and family managers both implement altruism on each other. Altruism is helpful to alleviate the agency problems of family businesses (Eaton et al., 2002).

Some scholars believe that altruism will exacerbate agency conflicts in family businesses and increase agency costs. In particular, after the start-up period of family businesses, new "moral hazards" may arise due to reasons such as cronyism, one-way altruism, and agency problems such as "free-riding" and "self-control" (Schulze et al. 2001, 2002, 2003a; 2003b). The altruism of parents is positively related to the children's shirk responsibility. The agency problem in the family will aggravate with the level of asymmetric altruism of the parents, leading to the "Samaritan dilemma". The "Samaritan dilemma" shows that the level of parental altruism is positively related to the children's tendency to be lazy and shirk responsibility. The agency problem in the family will worsen as the asymmetry of parental and child altruistic levels worsens (Buchanan, 1975). After the family business has reached a certain stage, altruism will increasingly cause agency problems. In core families and closer relationships, agency problems mainly come in the form of moral hazard, including shirk responsibility, free-riding, and on-the-job consumption. In the "quasi-family" based on distant kinship and social, cultural, religious and other factors, the agency problem mainly exists in the form of adverse selection. Altruism can cause parents to have a certain prejudice against the behavior of family agents, and can easily lead 
to wrong decisions (Karra et al., 2006).

Many other scholars believe that the impact of altruism on agency costs changes as family businesses are at different stages of development (Su Qilin, Zhang Qinglin, 2009; Karra et al., 2006). When business owners are able to distinguish between bidirectional altruism and single altruism, they can reduce agency costs and promote the intergenerational inheritance of family businesses that are "children and fathers" (Xu \& Zhou, 2008). From the dynamic perspective of the growth of family businesses, the impact of altruism on agency costs is dynamic. Altruism will reduce agency costs in the early stages of family business development. When family enterprises develop in the later period, altruism will increase agency costs (Chen, 2011).

In general, altruism, as a main feature of family businesses, has a complex and complex influence in the principal-agent relationship of family businesses, which is neither purely positive or purely negative, nor statically unchanged. Research from new perspectives such as housekeeping theory and organizational justice will help to better grasp the complex relationship between altruism and agency costs in family businesses.

\section{Research on Agency Costs of Family Firms in the Past Decade}

Family businesses are at the heart of social networks, and family members not only pursue economic goals, but also aim to maintain social emotional wealth (Cennamo et al., 2012). In the past ten years, scholars have added new perspectives and new thinking to the research of agency costs of family businesses, expanding the depth and breadth of research (Carney et al., 2012). Some scholars draw on relevant theories of psychology, and research has found that psychological ownership affects the agency problem of family businesses. In the absence of formal ownership, the sense of ownership of senior managers is able to align the interests of agents with the interests of clients. This transforms the agent into a psychological owner (Sieger, Zellweger, \& Aquino, 2013). Scholars consider the impact of the psychological factor of CEO organization identification on the extent to which companies bear agency costs, and research results show that CEOs with a high degree of organizational identity will avoid pursuing personal interests that may harm the company and its image 2018). When CEO organization recognition is high, board independence is unlikely to reduce agency costs (Boivie et al., 2011).

In addition, scholars focus on the impact of kinship on agency costs. The impact of altruism on agency costs was studied by improving Hamilton's affinity coefficient in evolutionary biology and introducing the concept of "sequence pattern" in native sociology (Wang et al., 2014). Based on the perspective of the stage of ownership development, the relative altruistic level of the actual controller of a family business can significantly reduce agency costs and improve agency efficiency. With the development of family business ownership from a single shareholder holding stage to a fraternal partnership stage to a family 
partnership stage, the enthusiasm of kinship and altruism to reduce agency costs has declined. In the stage of single shareholder holding and fraternal partnership, kinship altruism can significantly reduce agency costs and improve agency efficiency; in family partnership stage, kinship altruism can significantly reduce agency costs, but it has no significant effect on agency efficiency (Tan et al., 2018). The "home relationship" (surname-level relationship) between the CEO and the director has a significant impact on the agency cost of the company, and the "home relationship" will significantly increase the agency cost of the company. After controlling for endogeneity, this positive effect still exists significantly (Yan \& Xiao, 2019). The kinship in entrepreneurial family business affects agency costs. The possibility and extent of family members' involvement in business management can effectively reduce agency costs (Gu \& Wang, 2014).

Research on Governance Mechanism and Agency Cost of Family Business. The type and importance of governance mechanisms in family businesses are significantly different from non-family businesses. Family businesses are generally controlled by owner managers, rather than professional managers without significant ownership (Stewart \& Hitt, 2012). This source of control can sometimes reduce agency issues between owners and managers and agency issues between owner managers and creditors (Peng, Sun, Vlas, Minichilli, \& Corbetta, 2018), but sometimes generates owner agency Problems and the cost of agency problems between family owner managers and family members who are not directly involved in corporate governance. Establishing an intermediary governance mechanism in a family business may incur unique dual agency costs (Zellweger \& Kammerlander, 2015). Family business governance mechanisms can generally be divided into formal governance and informal governance. Research shows that informal governance can also play an important role in family businesses (Geletkanycz \& Boyd, 2011). This governance relies on social control mechanisms and is divided into positive mechanisms such as mutual trust, common attitudes and common values and negative governance mechanisms such as deprivation relationships and mutual monitoring mechanisms (Combs, Penney, Crook, \& Short, 2010). Internal informal governance mechanisms may be more important in family businesses than non-family businesses. Informal governance mechanisms can strengthen or offset family-specific formal governance mechanisms. Although the needs of the family coexist with the needs of the business, the competitive advantage of the family business may depend more on personal family relationships, which may generate social capital and survival capital (Nyberg et al, 2010). The impact of formal and informal governance mechanisms, both inside and outside corporate boundaries, should be an important part of future research agendas in this area (Chrisman \& Patel, 2012).

Other scholars have conducted related research from other perspectives. Empirical analysis of the relationship between audit quality, management mode and agency costs of family companies ( $\mathrm{Li} \& \mathrm{Su}, 2017$ ). From the perspective of corporate governance, the impact of venture capital on agency costs is studied. The results show that the agency costs supported by venture capital are lower, and 
the impact of venture capital on agency costs is regulated by entrepreneurial family companies (Peng et al., 2018).

\section{Conclusion}

By combing the research on the sources of agency costs, altruism and agency costs in family enterprises and reviewing the status quo of family enterprise agency costs research in the past decade, the following conclusions can be drawn: 1) The sources of family enterprise agency costs are the classic principal-agent problems and other sources. 2) In the field of family business research, there is controversy about whether altruism can reduce or increase agency costs. In addition to the principal-agent theory, it has also begun to conduct research by combining housekeeping theory and organizational justice and other methods. The research on agency problem is still in its immature stage and needs further development. 3) In the past ten years, scholars have studied the agency costs of family businesses from different entry points. The relationship between family characteristics and the relationship between governance mechanisms and agency costs are the focus of research.

It can be said that due to the interaction between the family and business systems under the changing internal and external environment, the agency cost problem is more complicated. Family companies face more agency problems than other types of companies, the types and the content of these agency problems also changes with the development stage of the family business. Future research questions can be: 1) How do heterogeneous interests among family owners affect conflicts among major shareholders? 2) Under what circumstances do family business managers' organizational identity and psychological ownership reduce the agency costs of professional agents? 3) How to alleviate agency conflicts through the configuration of governance structures (e.g. family committees, organizational structure adjustments)? Future research should follow deductive and inductive research strategies, and continue to provide support for the development and verification cycle of family business agency cost propositions, ultimately helping to develop and improve family business agency cost theory.

\section{Conflicts of Interest}

The authors declare no conflicts of interest regarding the publication of this paper.

\section{References}

Becker, G. S. (1981). A Treatise on the Family. Cambridge, MA: Harvard University Press.

Boivie, S., Lange, D., Mcdonald, M. L. et al. (2011). Me or We: The Effects of CEO Organizational Identification on Agency Costs. Academy of Management Journal, 2009, 551-576. https://doi.org/10.5465/amj.2011.61968081

Bruce, N., \& Waldman, M. (1990). The Rotten-Kid Theorem Meets the Samaritan's Di- 
lemma. Quarterly Journal of Economics, 105, 155-165.

https://doi.org/10.2307/2937823

Buchanan, J. M. (1975). The Samaritan's Dilemma. In E. S. Phelps (Ed.), Altruism, Morality and Economic Theory. New York: Russell Sage Foundation.

Carney, M., Essen, M. V., Gedajlovic, E. R. et al. (2013). What Do We Know about Private Family Firms? A Meta-Analytical Review. Entrepreneurship Theory \& Practice, 39, 513-544. https://doi.org/10.1111/etap.12054

Cennamo, C., Berrone, P., Cruz, C. et al. (2012). Socioemotional Wealth and Proactive Stakeholder Engagement: Why Family-Controlled Firms Care More about Their Stakeholders. Entrepreneurship Theory \& Practice, 36, 1153-1173.

https://doi.org/10.1111/j.1540-6520.2012.00543.x

Chen, J. L. (2011). Altruism, Agency Cost and the Growth of Family Business. Management Review, 23, 50-57.

Chrisman, J. J., \& Patel, P. C. (2012). Variations in R \& D Investments of Family and Nonfamily Firms: Behavioral Agency and Myopic Loss Aversion Perspectives. Academy of Management Journal, 55, 976-997.

Chrisman, J. J., Chua, J. H., \& Litz, R. A. (2010). Comparing the Agency Costs of Family and Non-Family Firms: Conceptual Issues and Exploratory Evidence. Entrepreneurship Theory \& Practice, 28, 335-354. https://doi.org/10.1111/j.1540-6520.2004.00049.x

Combs, J. G., Penney, C. R., Crook, T. R. et al. (2010). The Impact of Family Representation on CEO Compensation. Entrepreneurship Theory \& Practice, 34, 1125-1144. https://doi.org/10.1111/j.1540-6520.2010.00417.x

Corbetta, G., \& Salvato, C. A. (2004). The Board of Directors in Family Firms: One Size Fits All? Family Business Review, 17, 119-134.

Daily, C. M., \& Dollinger, M. J. (1992). An Empirical Examination of Ownership Structure in Family and Professionally Managed Firms. Family Business Review, 4, 117-135. https://doi.org/10.1111/j.1741-6248.1992.00117.x

Eaton, C., Yuan, L., \& Wu, Z. (2002). Reciprocal Altruism and the Theory of the Family Firm. Philadelphia, PA: Paper Presented at the Second Annual Conference on Theories of the Family Enterprise: Search for a Paradigm.

Eisenhardt, K. M. (1989). Building Theories from Case Study Research. Academy of Management Review, 14, 532-550. https://doi.org/10.5465/amr.1989.4308385

Fama, E. F., \& Jensen, M. C. (1983a). Agency Problems and Residual Claims. Journal of Law \& Economics, 26, 327-349. https://doi.org/10.1086/467038

Fama, E. F., \& Jensen, M. C. (1983b). Separation of Ownership and Control. Journal of Law \& Economics, 26, 301-325. https://doi.org/10.1086/467037

Franks, J., Mayer, C., Volpin, P., et al. (2012). The Life Cycle of Family Ownership: International Evidence. The Review of Financial Studies, 25, 1675-1712.

Geletkanycz, M. A., \& Boyd, B. K. (2011). CEO Outside Directorships and Firm Performance: A Reconciliation of Agency and Embeddedness Views. Academy of Management Journal, 54, 335-352. https://doi.org/10.5465/amj.2011.60263094

Gersick, K. F., Hampton, M. M., Lansberg, I., et al. (1997). Generation to Generation: Life Cycles of the Family Business. In Life Cycles of the Family Business. Harvard: Harvard Business School Press.

Gu, Z. H., \& Wang, W. J. (2014). Affinity and Agency Cost in Entrepreneurial Family Business. Journal of Management, 11, 1806-1817.

Jensen, M. C., \& Meckling, W. H. (1979). Rights and Production Functions: An Application to Labor-Managed Firms and Codetermination. Journal of Business, 52, 469-506. 
https://doi.org/10.1086/296060

Karra, N., Tracey, P., \& Phillips, N. (2006). Altruism and Agency in the Family Firm: Exploring the Role of Family, Kinship and Ethnicity. Entrepreneurship Theory and Practice, 30, 861-877. https://doi.org/10.1111/j.1540-6520.2006.00157.x

Li, J. M., \& Su, Y. M. (2017). Management Model, Audit Quality and Agency Cost of Family Business. Journal of Finance and Accounting, No. 33, 13-17.

Lubatkin, M. H., \& Schulze, W. S. (2007). An Organizational Justice-Based View of Self-Control and Agency Costs in Family Firms. Journal of Management Studies, 44, 955-971. https://doi.org/10.1111/j.1467-6486.2006.00673.x

Lubatkin, M. H., Ling, Y., \& Schulze, W. S. (2010). An Organizational Justice-Based View of Self-Control and Agency Costs in Family Firms. Journal of Management Studies, 44, 955-971. https://doi.org/10.1111/j.1467-6486.2006.00673.x

Mitchell, R., \& Meacheam, D. (2011). Knowledge Worker Control: Understanding via Principal and Agency Theory. Learning Organization, 18, 149-160.

https://doi.org/10.1108/09696471111103740

Morck, R., \& Yeung, B. (2010). Agency Problems in Large Family Business Groups. Entrepreneurship Theory \& Practice, 27, 367-382. https://doi.org/10.1111/1540-8520.t01-1-00015

Nyberg, A. J., Fulmer, I. S., Gerhart, B. et al. (2010). Agency Theory Revisited: CEO Return and Shareholder Interest Alignment. Academy of Management Journal, 53, 1029-1049. https://doi.org/10.5465/amj.2010.54533188

Peng, M. W., Sun, W., Vlas, C. et al. (2018). An Institution-Based View of Large Family Firms: A Recap and Overview. Entrepreneurship Theory \& Practice, 42, 187-205. https://doi.org/10.1177/1042258717749234

Peng, T., Huang, F. G., \& Li, S. Y. (2018). The Impact of Venture Capital on the Agency Cost of Enterprises: A Perspective of Corporate Governance. Management Science, 31, 62-78.

Salvato, C., \& Corbetta, G. (2013). Transitional Leadership of Advisors as a Facilitator of Successors Leadership Construction. Family Business Review, 26, 235-255.

Schulze, W. S., Lubat Kin, M. H., Ling, Y., \& Dino, R. N. (2002). Altruism Agency and the Competitiveness of Family Business. Managerial \& Decision Economics, 23, 247-259. https://doi.org/10.1002/mde.1064

Schulze, W. S., Lubatkin, M. H., Dino, R. N. et al. (2001). Agency Relationships in Family Firms: Theory and Evidence. Organization Science, 12, 99-116. https://doi.org/10.1287/orsc.12.2.99.10114

Schulze, W., Lubatkin, M., \& Dino, R. (2003a). Toward a Theory of Agency and Altruism in Family Firms. Journal of Business Venturing, 18, 473-490. https://doi.org/10.1016/S0883-9026(03)00054-5

Schulze, W., Lubatkin, M., \& Dino, R. (2003b). Exploring the Agency Consequence of Ownership Dispersion among the Directors of Private Family Firms. Academy of Management Proceedings, 46, 179-194. https://doi.org/10.5465/30040613

Sieger, P., Zellweger, T., \& Aquino, K. (2013). Turning Agents into Psychological Principals: Aligning Interests of Non-Owners through Psychological Ownership. Journal of Management Studies, 50, 361-388. https://doi.org/10.1111/joms.12017

Stewart, A., \& Hitt, M. A. (2012). Why Can't a Family Business Be More Like a Nonfamily Business? Modes of Professionalization in Family Firms. Social Science Electronic Publishing, 25, 58-86. https://doi.org/10.1177/0894486511421665

Tan, Q. M., Wang, C., Zhou, Y. X., \& Qu, D. (2018). Effects of Kinship Altruism on 
Agency Costs in Family Business-Based on the Perspective of the Development Stage of Ownership. Economic Issues, No. 3, 57-65.

Vanden Berghe, L. A. A., \& Carchon, S. (2003). Agency Relations within the Family Business System: An Exploratory Approach. Corporate Governance: An International Review, 11, 171-180. https://doi.org/10.1111/1467-8683.00316

Wang, M. L., Xu, M. N., \& Wang, H. S. (2014). Can Altruistic Behavior Reduce Agency Costs?-An Empirical Study Based on Relative Altruistic Behavior in Family Businesses. Economic Research, 49, 144-157.

Xiang, D., Worthington, A. C., \& Higgs, H. (2014). Family Ownership, Altruism and Agency Costs in Australian Small- and Medium-Sized Enterprises. Applied Economics, 46, 3907-3921. https://doi.org/10.1080/00036846.2014.946183

$\mathrm{Xu}$, M. N., \& Zhou, S. C. (2008). Research on Agency Problem and Intergenerational Succession of Family Business from the Perspective of Altruism. Foreign Economy and Management, No. 7, 52-57.

Yan, W. H., \& Xiao, X. (2019). "My Family Relationship" between CEO and Director Increases Agency Cost? Management Review, 31, 99-116.

Zellweger, T., \& Kammerlander, N. (2015). Family, Wealth, and Governance: An Agency Account. Entrepreneurship Theory \& Practice, 39, 1281-1303.

https://doi.org/10.1111/etap.12182 